\title{
The Effect of Gawang Ceria Games for Gross Motor Skills With Thematic Learning Approach at Bahari Kindergarten in Padang
}

\author{
Rakimahwati $^{1 *}$, Cindy $^{1}$ \\ ${ }^{I}$ Early Childhood Education, Universitas Negeri Padang, Indonesia \\ *Corresponding author. Email: rakimahwati10@yahoo.com
}

\begin{abstract}
This research is based on the unpredictability of children's gross motor skills optimally, the majority of children could not yet boarding the board, catch and throw the ball, put the ball into the goal provided. Learning or a race to develop a child's gross motor has begun to draw but the games that children do such as throwing games and catching the ball have not affected the gros motor development of children's. This study aims to see the effect of the game activity Ball Goalkeeper to the development of gross motor of children with thematic learning in group B at Bahari Kindergarten.This research uses Quantitative approach with Quasy Experiment method. The research population is all children of Kindergarten Bahari Padang and sampling technique purposive sampling, that is class B2 (experiment class) and class B3 (control class). Technique of collecting data using test, data collecting instrument through observation. Then the data is processed by difference test (t-test). Based on the results of the pre-test group experimental data obtained from motor skills mentioned, it is seen that the highest score achieved by the child is 75 and the lowest score is 60 . The control group of the pre-test result of motor ability, it is seen that the highest score achieved by the child is 70 and the lowest score is 60 . Then it can be concluded that there is a significant influence of cheerful ball game activity on the development of gross motor skills of children with thematic learning at Bahari kindergarten in Padang.
\end{abstract}

\section{Keywords: Gross Motor Skills, Thematic Learning Approach, Kindergarten}

\section{INTRODUCTION}

Early childhood education is the first step for children who should be able to reach the level of children development, because the development takes place with the stage of children development.The development of children would be different because influenced by internal and external factors),so that every child will experience the same pattern of development. The existence of early childhood education services with kindergarten programs, the role and participation of children in these activities will improve all through learning activities as well as play activities and games at school. "One aspect of child development that need to be optimized from an early child-hood is gross motor skills, because its existence is essential to maximize growth and development of the child's body that further supporting the optimization of another aspect development" [1].

The results of observations by researchers at the Bahari Kindergarten when doing the learning to develop gross motor child is still low, for example, when the children climbed the board of the footway is still looks children do not have a good balance, so there are some children who fell from the board of the catwalk. In addition, when a child performs a throwing game and catches a ball, a few children can not throw the ball right to their friends, so their friend can not catch the ball because the lane is not yet directed. Then, can be seen also when children play football, there are some children who have not been able to enter or kick the ball into the goal. Often the kid's kick is not right into the goal. It is seen that gross motor development is still low. Besides that, it is caused by one of the teachers is

"to give the game about the gross motor, so that children are not motivated for gross motor development.Gross motor is movement that involving some oral the limbs in need organizing the muscles great accompanied by the deployment of many exertion to achieve an objective skills that include locomotor, nonlocomotor and motion manipulative"[2].

Gawang Ceria game is a game to play with a ball and use a rubber ball of the same size, then the one that will measure the two of them with the humans. Gawang Ceria game is a cheerful game, where it is played in the ball for the ball to be called in to demand the ball into the precise arm of the opponent. The game is followed by a cheerful 
gamelan, during which the game is allowed to play, but whenever it is declared a player has to stop play and change in the sculptures, so it goes to the game to end. In this event, we will look at the cheerfulness in this Gawang Ceria game.

Relevant research relates to gross motor development that is about Differance Children Gross Motor Skills between Two Types of Preschool. This study focuses on educational goals that affect preschool types (common vs. private) in the development of motor skills of kids ages 3 to 6.5 years. Educators provide some tests on which motor development is based. The analysis performed to look at the age of the child demonstrating the locomotor skills of children derived from private preschools is better than in public schools.

"The next relevant study entitled an increase in rough motor skills through traditional Javanese games" [2]. This research focuses on the purpose of improving rough motor skills through traditional Javanese games and knowing the improvement of B group gross motor skills inTK Pertiwi Trenggalek through traditional Javanese games. The conclusions of gross motor gross pregnancy can be improved through traditional Javanese games.

Researchers together with collaborators work together in developing abusive motor skills of children with Gawang Ceria game. Based on the above background explanation, the purpose of the research is to explain the effect of Gawang Ceria game on the development of gross motor with the thematic approach in Bahari Kindergarten Padang.

\section{Raw Motorial Ability}

"According to Hurlockthat motor development means the control of the physical movement through the nerve center activities, nerves and muscles are mutually coordinated" [3] Motion skills, including: locomotor, nonlocomotor, and manipulative motion. Locomotor motion can be said that locomotor motion skills include moving body movements.Locomotor movement (fundamental movement) is the ability to move the whole body from one place to another. "This is demonstrated by craw-ling, creeping, walking, running, jumping, hopp-ing, skipping and climbing according to Jackman" [4]. Locomotor motion is the ability to move the body from one place to another. For example, roll over, creep, walk, run, jump, jump and climb. Locomotor motion skills help the child's awareness of the concept of space. "(Gross motor skill in which an object is usually involved (mani-pulated). This demonstrated by pulling, pushing, lifting, striking, throwing, kicking and ball catching " [4]. According to [5] "Motor development of children is change of motor ability from infant to adult that involve various aspect of behavior and motor ability". Based on some notions described by the experts, it can be concluded that abusive motor skills are the ability associated with the movement of large muscles in controlling body movement through locomotor capability, non-locomotor, and manipulative."Then Motor skills are an essential component of development for all children. Children need to move a lot" [6].

Gawang Ceria game, this game is one form of game from a handball that was modified by the researchers into a cheerful ball game. Because, in this game there is the same activities as throwing and catching the ball in a handball game.Handball games include many popular games from various quarters because this game is a fun game, cheap and simple equipment and could be played by everyone in the open field.

Gawang Ceria game is very well done to maintain the physical fitness of a person because in this handball game there are elements that are: (1) dynamic motion, (2) have high sportsmanship, (3) full creative power, (4) perfect from the movements performed, (5) Forming perseverance and is a reflection of personality of a person to hunt.Activity in Gawang Ceria game is First, throw the ball. Second, Catch the ball. Third, Running.

\section{Temperical Approach}

Thematic learning can be interpreted as a lesson by integrating the material of several subjects in one theme / topic of discussion. In addition, thematic learning will provide integrated learning opportunities that place more emphasis on student participation or involvement in learning. The basis of applying and implementing thematic learning, there are several basic principles that need to be considered: 1) integrated with the environment, 2) the form of learning is designed so that students find the theme, and 3) the efficiency of time, material burden, method, and the use of authentic learning resources. "Thematic learning is taught in children because in general they still see everything as a whole (holistic) physical development can not be separated with social mental, and emotional according to" [7].

\section{METHODOLOGY}

The research method used in this research is quasi experiment. Quasy experiment is a research procedure proposed to determine the effect of a deliberate condition on the situation, activity or behavior of individuals or groups of individuals. "Quasi Design Experiments have kontorl, but can not function fully to control the outside variables that influence the implementation of the experiment accordingly Population is a generalization region consisting of objects or subjects that have the quality and characteristics set by researchers to be studied and then drawn conclusions"[8]. The population of this research is all group B BahariKindergarten.

\section{RESULTS}

The RESULTS showed that the motor skills of children in Bahari Kindergarten in experimental class and control class showed that the motor skills of the experimental group (group B2) were higher than the control group (B3 group). To test the hypothesis used t-test. From result of hypothesis test by using t-test obtained tcount result bigger than ttable $(7,86>2,101)$. With $\mathrm{dk}(\mathrm{N} 1-1)+(\mathrm{N} 2-1)=18$. In table df for the real level $\alpha=0.05$ (5\%) obtained ttable price $=2.101$ maka it can be said that the hypothesis $\mathrm{Ha}$ accepted or Ho rejected. It can be concluded that there is a significant difference between the post-test results (endcapability) of children in the experimental group and the control group in the motor skills of children. 
After the calculation of pre-test and post-test of the experimental and control group, then there will be a comparison between the pre-test and post-test value, which aim to see whether there is difference of post-test value and the pre-test value of the child.

Table 1. Comparison of Calculation Result of Pre-Test Value and Post-Test Value

\begin{tabular}{|c|c|c|c|c|}
\hline \multirow{2}{*}{ Variabel } & \multicolumn{2}{|c|}{ Pre-test } & \multicolumn{2}{c|}{ Post-test } \\
\cline { 2 - 5 } & Treatment & Control & Treatment & Control \\
\hline The higest & 75 & 70 & 100 & 80 \\
\hline The Lowest & 60 & 60 & 85 & 65 \\
\hline Average & 67,5 & 63,5 & 90,5 & 70,5 \\
\hline
\end{tabular}

Based on the above table, we can compare the RESULTS of the pre-test and post-test values. In the pretest, the highest score in the experimental group was 75 and the control group was 70 and the lowest score for the experimental group was 60 and control 60, the mean value obtained by the child was 67.5 for the experimental group and 63.5 for the control group. After the post-test the value of the child increases in both groups.

The comparison of children's visible values in the experimental group grew larger than the control group, ie the highest score achieved by the children in the experimental group was 100, the control group was 70.5 and the lowest score obtained by the experimental group was 85 and the control was 65 . Furthermore, the average value obtained by the experimental group children 90.5 while the control 70.5 .

Comparison of the results of the calculation of pre-test and post-test values is seen at the highest and lowest values obtained by the child and is seen in the average experimental group and control group in the post-test where the average post-test becomes more than the average average pre-test after treatment.

Based on the description of the table above, it can be seen that the motor skills of children in the experimental group is higher than the control group. For more details can be seen in Graph 1. below:

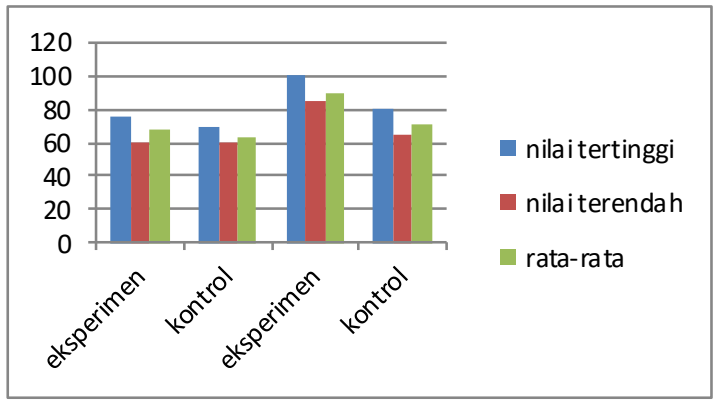

Graph 1 Comparative Data on Pre-Test and Post-Test results Gross Motor Ability of Children in Experiment Class and Control Class

Based on the graph above, it can be concluded that the activity of a cheerful ball game affect the child's rough motor compared to the ball ball activity. The research that has been done by taking samples of 10 children with age range 5-6 years and conducted as many as five times meeting consisting of one time pre-test, three times treatmant (treatment), once done post-test. In the experimental class conducted by the researcher and in the control class was done by the class teacher observed by the researcher on pre-test and post-test.

Based on the results of pre-test of abusive motor abilities of children in the experimental class and control class on the pre-test obtained the average number of experimental class is 67.5. The average number of control class is 63,5 . Based on the result of data analysis that has been done that $t$ arithmetic equal to 1.86 compared with $\alpha$ $0,05\left(\mathrm{t}_{\text {table }},=2,101\right)$ with degree of freedom dk $(\mathrm{N} 1-1)+$ $(\mathrm{N} 2-1)=18$. Thus thitung <ttabel, that is $1.86<2.101$, it can be said that the hypothesis Ha rejected or $\mathrm{H}_{0}$ accepted.

So it can be concluded that there is no significant difference between motor skills of experimental class and control class. Then, based on motor skills RESULTS in the experimental class and control class on the post-test, the average experiment class is 90.5 and the average score the average control class is 70.5 .

Based on the results of data analysis that has been done that tcount of 7.75 compared with $\alpha 0.05\left(\mathrm{t}_{\text {table }},=2.101\right)$ with degrees of freedom $\mathrm{dk}(\mathrm{N} 1-1)+(\mathrm{N} 2-1)=18$. Thus $t_{\text {count }}>t_{\text {table }}$, ie $7.75>2.101$ then it can be said that the $H_{a}$ hypothesis is accepted or $\mathrm{H}_{0}$ is rejected.

It can be concluded that there is a significant influence from the activity of the cheerful ball sphere on the abusive motor skills in the Bahari Padang Kindergarten, because in this cheerful ball game the researcher implements an interesting game to the child. For example, when the child performs the game, during the game go through the goal ball cheerful accompanied by happy music and if in the middle of the game the music is stopped, the child should not move or turn into a statue and when the music is revived the child may continue the game ball cheerful goal.

"Motoric is one of the most important aspects for early childhood means the development of physical movement control through the activities of nerve centers, nerves, and controlled muscles" [9] Gross motor is the ability of early childhood activities by using large muscles. "The ability to use these large muscles for the child is categorized in the ability of abilities to improve the quality of life according to" [10].

One of the things can help the motor development of the children through play. "Playing is an activity performed with or without the use of tools, which generate understanding and provide information, give pleasure and develop children's imagination according to" [11]. Based on the above opinion, it can be concluded that the Cheetah Goalkeeper activity can affect the development of rough motor skills of children. When the researchers used the Cheetah Ball activity in the experimental class (B2) at the Bahari Padang Kindergarten, all the children looked enthusiastic and enthusiastic to do the cheerful ball game activity. 
While in the control class (B3) using ring ball activity to develop their gross motor. Ring ball is a game of children putting the ball into the ring. But, sometimes the use of this ball game feels less appealing to the children of the six basketball players, because they are often reinstated, making them ridiculous when they are playing in the game, but not in the explanation of the money they are causing the players to be less organized.Based on the observation of the researcher, the results of the motor skills in the class of the experiments were better than the targeted motor skills in the control group. The conclusion of a cheerful ball goal influenced the motor skills in the Bahari Padang Kindergarten. Finally, The availability of quality human resources who have excellent physical, mental and social conditions and mastery of science and technology are indicators of the success of a nation's development" [12].

\section{CONCLUSIONS}

Based on the results of the research conducted in the Kindergarten of Padang Bahari, the results of the motor skills in the experimental class (B2) with Gawang Ceria activity were higher than the control class (B3) who used Ring Ball activities, (90.5) for the experimental class and $(70,5)$ for the control class.

In the hypothesis test obtained $t_{\text {count }}>t_{\text {table }}$ where $7.86>$ 2.101 is evidenced by significant level $\alpha 0,05$ this means there is a significant difference between the RESULTS of gross motor abilities of children in the experimental class that use activities Ball Goalkeeper with control classes that use the activities Ring Ball.

Gawang Ceria games is proven to have an effect on developing grossmotor skills in Kindergarten of Padang. This can be seen from the motor skills of children can develop well in the activities of catching and throwing the ball into the goal.

\section{REFERENCES}

[1] S. dkk Hayatul, "Effect Of Traditional Games, Learning Motivation and Learning Style on Childhoods Gross Motor Skills," vol. 5, no. 7, pp. 53-66, 2017.

[2] N. I. Kadek and A. Rahmadani, "Pertiwi Kabupaten Trenggalek sela- Permainan tradisional Jawa," pp. 305-314.

[3] E. Hurlock, perkembangan anak jilid 1, 6th ed. jakarta: erlangga, 1997.

[4] H. L. Jackman, Early Education Curriculum Fifth Edition. belmot: wadworst, 2012.

[5] Samsudin, Pembelajaran Motorik di Taman Kanak-Kanak. jakarta: litera, 2008.

[6] P. Shanti, "Development of Educational Toy: Jumping Alphabet Stages of Writing and Reading," vol. 58, pp. 385-389, 2017.
[7] Yuliani, Konsep Dasar PAUD. jakarta: unj, 2007.

[8] Sugiyono, Metode Penelitian Pendidikan. Bandung: Alfabeta Pustaka Utama, 2011.

[9] Syafril, Statistika. Padang: Sukabina Press, 2010.

[10] M. Sumantri, Model Pengembangan Keterampilan Motorik Anak Usia Dini. jakarta: depdiknas, 2005.

[11] A. Triharso, Permainan Kreatif \& Edukatif Untuk Anak Usia Dini. yogyakarta: penerbit amdi, 2013

[12] Z. Zulbahri, "Tingkat Kemampuan Daya Tahan Jantung dan Pernafasan Mahasiswa Pendidikan Olahraga dan Kesehatan Universitas Pasir Pengaraian", Gelanggang Olahraga: Jurnal Pendidikan Jasmani dan Olahraga, vol. 3, no. 1, pp. 96-101, Oct. 2019. 